\title{
ANALIZA FINANCIJSKIH IZVJEŠTAJA U FUNKCIJI DONOŠENJA KVALITETNIJIH UPRAVLJAČKIH ODLUKA
}

\author{
mr.sc. Željko Tintor \\ Retra d.o.o. za reviziju i poslovno savjetovanje u Zagrebu \\ Lastovska 6, Zagreb, Hrvatska \\ e-mail: retra@zg.htnet.hr
}

\section{SAŽETAK}

Zaplaniranje ivođenje poslovanja nužnaje adekvatna informacijska podloga zainteresiranim korisnicima. Informirati korisnike znači predočiti im relevantne i pouzdane informacije u prepoznatljivom obliku i sadržaju razumljivom korisnicima kojima su namijenjene. Najveći dio tih informacija nastaje u računovodstvu. Konačni proizvod računovodstvenog procesa je skup izvještaja koji se nazivaju financijskim izvještajima. Oni izvještavaju o stanju poduzeća i uspješnosti poslovanja te upozoravaju na moguće probleme. Financijski izvještaji koje sastavljaju poduzetnici definirani Zakonom o računovodstvu jesu: bilanca, račun dobiti i gubitka, izvještaj o novčanom toku, izvještaj o promjenama glavnice i bilješke uz financijske izvještaje. Financijsko izvještavanje mora osigurati: pouzdane informacije za donošenje upravljačkih odluka, upotrebljive informacije sadašnjim i potencijalnim investitorima i kreditorima za donošenje odluka o ulaganjima i kreditima, informacije o resursima poduzetnika i njihovim izvorima, o transakcijama koje utječu na promjene resursa i izvora, informacije o uspješnosti poslovanja u određenom razdoblju, kao i informacije stručnjacima koji žele proučavati stanje i poslovanje u prošlosti u svezi s planiranjem i sl. Osim vlasnicima i menedžmentu, informacije o stanju i poslovanju poduzeća može biti interesantno i drugim skupinama kao što su: poslovni partneri, investitori, banke, državne institucije i sl. Svaka od tih skupina, sobzirom na razloge i motive promatranja, usmjerena je na određene aspekte financijskih informacija. Onima s računovodstvenim znanjem, skup financijskih izvještaja je razumljiv, a ukoliko su i revidirani preko neovisnih revizora, tada im je to i pouzdan izvor informacija za njihove potrebe. Međutim, veliki je broj onih koji nisu računovodstveni stručnjaci i kojima je potrebno odgovarajuća interpretacija financijskih izvještaja. Interpretacija podrazumijeva analizu financijskih izvještaja korištenjem složenog instrumentarija financijske analize. Kao sredstva analize koriste se analitičke tehnike: vrijednosne i postotne promjene, trend u postotcima, komponente u postotcima te pokazatelji i sustavi pokazatelja. U radu se primjenom relevantnih analitički metoda $i$ tehnike provodi analiza financijskog izvještaja odabranog poduzeća. Cilj je ovog rada da pokaže kako se, primjenom analitičkih metoda i tehnika, mogu interpretirati podaci koji 
se pojavljuju u financijskim izvještajima, a za potrebe vlasnika i menadžmenta, kreditora $i$ drugih korisnika.

Ključne riječi: financijski izvještaji; financijske informacije; analiza financijskih izvještaja; analitičke metode i tehnike; interpretacija financijskih izvještaja

\section{UVOD}

Polaznu osnovu u izučavanju ove problematike čini pretpostavka da je poduzeće poslovno financijski sustav u kojem menadžeri svakodnevno donose odluke kojima utječe na pribavljanje, kretanje i alokaciju sredstava poduzeća. Pri tome su tokovi sredstava usmjereni prema investicijama, poslovanju i financiranju, a odluke kojima se oni usmjeravaju obuhvaćaju investicijske odluke, odluke o poslovanju i odluke o financiranju.

Investicijske su odluke ključne jer se njima pokreće poslovanje i omogućuje provedba strategije razvoja. One uključuju usmjeravanje postojećih i/ili pribavljenih kapitalnih sredstava za ulaganje u: (1) dugotrajnu imovinu koja čini infrastrukturu nužnu za poslovanje, (2) obrtni kapital potreban za tekuće poslovanje i (3) istraživanja i razvoj novih proizvoda, tržišta i sl. Odluke o poslovanju usmjerene su na politiku prihoda i na djelotvornu kontrolu i optimalizaciju troškova poslovanja. Odluke o financiranju podrazumijevaju poslovne odluke o korištenju neto dobiti odnosno na njezinu podjelu između vlasnika, vjerovnika i zadržavanja za potrebe investiranja, dok odluke o strukturiranju kapitala poduzeća imaju za cilj osiguranje primjerenog vlasničkog kapitala i optimalizaciju omjera sredstava iz vlastitih izvora tj. uloženog i zarađenog kapitala i tuđih dugoročnih izvora. Svaka od navedenih skupina upravljačkih odluka zasniva se na određenom konceptu informacija dobivenih autorovom analizom financijskih izvještaja. Za prvu skupinu relevantan je pokazatelj stope profitabilnosti odnosno stope povrata investiranog kapitala, za drugu su to pokazatelji efikasnosti korištenja sredstava prema računu prihoda, rashoda i dobiti i dr., dok su za treću skupinu relevantni pokazatelji neto dobit po dionici, profitabilnost vlasničke glavnice i drugi pokazatelji. Cilj je rada pokazati kako se analizom financijskih izvještaja mogu dobiti i interpretirati značajni podaci u funciji donošenja kvalitetnijih upravljačkih odluka. Temeljne hipoteze rada su: H1. Analiza financijskih izvještaja usmjerena je na ispitivanje vrijednosnih podataka prikazanih u financijskim izvještajima, H2. Primjenom analitičkih metoda i tehnika podaci iz financijskih izvještaja pretvaraju se u informacije relevantne za donošenje upravljačkih odluka i H3. Interpretacija podataka i informacija dobivenih analizom financijskih izvještaja u funkciji je donošenja kvalitetnijih upravljačkih odluka. Primarno istraživanje autora obuhvaća analizu financijskih izvještaja odabranog poduzetnika, dok su sekundarna istraživanja obuvatila relevantnu znanstvenu i stručnu literaturu za postavljanje okvira istraživanja. Metode rada obuhvaćaju primjenu analitičkih metoda i tehnika, a dobiveni su rezultati komparativno prikazani u prezentiranim tablicama $s$ komentarima i zaključcima. 


\section{IZVORI FINANCIJSKIH INFORMACIJA}

Da bismo mogli osigurati pravodobno i kvalitetno odlučivanje menadžera i drugih zainteresiranih skupina, potrebno je posegnuti za izvorima informacija pomoću kojih se prati poslovanje i rezultati poslovanja, a koji nam omogućuju da primjenom analitičkih metoda i tehnika osiguramo pokazatelje koji nam pomažu u donošenju poslovnih odluka. Obično je to skup javno objavljenih financijskih izvještaja sastavljenih prema propisima i računovodstvenim standardima, a koji javnosti pružaju temeljne podatke o poslovanju i rezultatima poslovanja poduzeća poduzetnika. „Financijski izvještaji služe kao kontrolna ploča s mjernim instrumentima. Oni izvještavaju o radu menadžera, potvrđuju njihove uspjehe i neuspjehe i upozoravaju na probleme. Tumačenje informacija koje daje složena kontrolna ploča zahtijeva poznavanje instrumenata i njihova prilagođavanja kako bi se razumjeli dobiveni podaci“ (Meigs\&Meigs, 1999., str. 923.). Temeljne financijske izvještaje čini skup koji najčešće obuhvaća: (a) bilancu, (b) račun dobiti i gubitka, (c) izvještaj o novčanom toku , (d) izvještaj o promjenama kapitala (glavnice) i (e) bilješke uz financijske izvještaje, pripremljenih u skladu s propisima i općeprihvaćenim računovodstvenim standardima, koji osiguravaju njihovu autentičnost, transparentnost i usporedivost. Sadržajno svaki od njih daje određeni prikaz stanja i poslovanja kao rezultat prošlih upravljačkih odluka. „Svi ti izvještaji međusobno su povezani i upućeni jedni na druge. Neki su statičkog karaktera jer pokazuju situaciju u određenoj točki vremena, a drugi pokazuju promjene ekonomskih katergorija u određenom razdoblju te stoga imaju dinamički karakter. Promatrani zajedno, u međusobnoj interakciji, govore o „zdravstvenom stanju“ nekog poduzeća, a utvrditi i razumijeti to „stanje“ znači imati mogućnost donositi primjerene i racionalne poslovne odluke" (Grupa autora, redaktor Lajoš, Ž., 2008.str. 52.). Kako analize financijskih izvještaja počivaju na informacijama sadržanim u tim izvještajima, potrebno je razumjeti njihov obuhvat, značajke i ograničenja u svrhu ispravne interpretacija podataka i informacija dobivenih analizom financijskih izvještaja.

\subsection{Bilanca}

Bilanca je jedan od temeljnih financijskih izvještaja, koji pokazuje financijsko stanje poduzetnika na određeni dan. Sadržajno svojim obujmom i strukturom, bilanca obuhvaća imovinu i izvore te imovine u formi obveza i kapitala na određeni dan, redovito na kraju poslovne godine. Dakle, temeljni segmenti bilance $s$ jedne strane jesu imovina sadržana $u$ aktivi bilance, te kapital i obveze sadržani u pasivi bilance, kao izvori financiranja ukupno raspoložive imovine u aktivi bilance.

Aktivu bilance pokazuje sadržaj i strukturu ukupno raspoložive vlastite imovine poduzeća. Najvažnije su kategorije imovine: (a) stalna imovina koja se koristi dugoročno i (b) tekuća imovina koja se koristi kratkoročno. Kombinacijom kriterija vrste, pojavnih oblika i trajnosti, imovina kojom raspolaže poduzeće u bilančnoj aktivi prikazana je prema kriteriju rastuće likvidnosti, što znači da su na prvom mjestu prikazane vrste i oblici dugotrajne imovine, a potom vrste i oblici kratkotrajne imovine. U aktivi bilance dugotrajna je imovina klasificirana u skupine kao: nematerijalna imovina, materijalna imovina, financijska imovina i potraživanja, a kratkotrajna se imovina klasificira kao: zalihe, potraživanja, kratkotrajna financijska imovina i novac u banci i blagajni. Tako klasificirane kategorije imovine dalje se analitički prikazuju u podskupinama po vrstama imovine. 
U pasivi bilance, izvori angažirane imovine klasificirani su na: (a) kapital kao vlastite izvore imovine i obveze kao tuđe izvore imovine s tim da su obveze raščlanjene na (b) tekuće obveze s dospijećem do godine dana i (c) dugoročne obveze koje su plative u roku duljem od godine dana. Kapital i obveze također se dalje analitički razrađuju i prikazuju u podskupinama po vrstama izvora financiranja.

Temeljna značajka bilance jest koncept dvostranog promatranja odnosno bilančna ravnoteža imovine s jedne strane i kapitala i obveza s druge strane. Navedena ravnoteža ne govori ništa o financijskom stanju poduzetnika. Tek izučavanje njezine strukture upućuje na određena stanja poduzetnika. Primjerice, cjelokupna imovina prikazana u aktivi jest u formalno pravnom vlasništvu poduzetnika. Međutim, samo kapital pokazuje koji je dio imovine u stvarnom vlasništvu poduzetnika, a koji je dio u tuđem vlasništvu (vjerovnici) i koliko iznose neotplaćene obveze u pasivi bilance ili pak kakav je odnos vlastitih i tuđih izvora što upućuje na stupanj zaduženosti poduzetnika.

\subsection{Račun dobiti i gubitka}

Račun dobiti i gubitka jedan je od temeljnih financijskih izvještaja, koji prikazuje učinke ranijih poslovnih odluka na poslovanje. Pokazuje obujam i strukturu prihoda i rashoda i dobit odnosno gubitak kao financijski rezultat njihova sučeljavanja u određenom obračunskom razdoblju, najčešće tijekom kalendarske godine.

Osnovni model u našoj praksi obuhvaća poslovne i financijske prihode s jedne strane i poslovne i financijske rashode s druge strane sučeljavanja, gdje se kao rezultat pojavljuje dobit ili gubitak prije poreza, a potom nakon odbitka poreza na dobit, kao dobit ili gubitak nakon poreza. Klasifikacija prihoda i rashoda dodatno je analitički razrađena u podskupine i vrste prihoda i rashoda. Bitna karakteristika računa dobiti i gubitka jest da se u njemu prikazani rashodi klasificirani po prirodnim vrstama troškova, što predstavlja ograničavajući faktor za dio financijskih analiza i interpretaciju njihova rezultata. Širi model računa dobiti i gubitka obuhvaća još i prihode i rashode od udjela u dobiti i gubitku od društava s povezanim sudjelujućim interesom odnosno od zajedničkih pothvata.

\subsection{Izvještaj o novčanom toku}

Izvještaj o novčanom toku jedan je od temeljnih financijskih izvještaja, koji pokazuje obujam i strukturu priljeva i odljeva novca i novčanih ekvivalenata u obračunskom razdoblju. „U osnovi, izvješće o novčanom toku gospodarskog subjekta sličan je po tome što sažima bezbroj specifičnih novčanih transakcija u nekoliko kategorija. Međutim, u praksi se informacije za izvješće o novčanom toku ne dobivaju izravno s konta novca i novčanih ekvivalenata, već se izvode iz podataka RDG i bilance" (Robert N. A. i James. S.R., 2004. str. 244.). Njegova je svrha da poput računa dobiti i gubitka također prikaže promjene u financijskom položaju poduzetnika kao rezultat odluka donesenih u promatranom obračunskom razdoblju. Razlike je u tome što pod utjecajem obračunskog načela, nerijetko imamo pojavu u poduzećima da ostvaruju visoke prihode i dobit poslovanja koje, najčešće zbog neplaćanja, ne prati tekuća likvidnost, ili pak imamo suprotne situacije u kojima poduzeće može iskazivati gubitak u poslovanju, a istodobno zbog naplate ranijih potraživanja može imati pozitivan novčani tok. 
Svi novčani tokovi klasificiraju se u tri skupine aktivnosti kao novčani tokovi od: (a) poslovnih aktivnosti, (b) investicijskih aktivnosti i (c) financijskih aktivnosti. Izvještaj se sastavlja tako da se uspoređuju početna i konačna stanja u bilanci, a koriste se i podaci iz izvještaja o poslovanju. Može se sastaviti primjenom direktne ili indirektne metode. Prema direktnoj metodi izvještaj pokazuje bruto novčane primitke i izdatke za svaku aktivnost, dok indirektna metoda polazi od neto financijskog rezultata (dobitka ili gubitka) koji se korigira za iznos amortizacije i promjena nenovčanih bilančnih stavaka, te za ostale stavke čiji su novčani učinci investicijski ili financijski tokovi. U praktičnoj primjeni susrećemo korištenje obje metode izrade novčanog toka, ali postoje i situacije u kojima je za potrebe financijskih analiza jedino moguće koristiti indirektnu metodu izrade novčanog toka.

\subsection{Izvještaj o promjenama kapitala}

Izvještaj o promjenama kapitala (glavnice) jedan je od temeljnih financijskih izvještaja, koji pokazuje promjene na vlasničkom kapitalu. Promjene nastaju kao rezultat odluka menadžera od utjecaja na vlasnički kapital. Primarni utjecaj na njegove promjene ima rezultat poslovanja iskazan u računu dobiti i gubitka, ali i druge odluke, poput isplata dividenda, dokapitalizacija, dekapitalizacija, formiranjem kapitalnih rezervi i sl. Sadržajno, izvještaj daje određene informacije o financijskom stanju poduzetnika, ali za razliku od prethodnih financijskih izvještaja ovaj se izvještaj smatra pomoćnim u smislu boljeg razumijevanja bilance.

\subsection{Bilješke uz financijske izvještaje}

Bilješke uz financijske izvještaje jedan su od temeljnih financijskih izvještaja, koje sadrže dodatne i dopunske informacije koje nisu prezentirane u prednjim financijskim izvještajima. Svojim sadržajem daju temeljne informacije o poduzetniku i njegovim računovodstvenim politikama, te analitički prikaz i tumačenja kategorija ostalih financijskih izvještaja, posebice onih gdje su korištene alternativne metode obračuna. Tako strukturirane daju značajan doprinos razumijevanju informacija u financijskim izvještajima, mada se izravno ne koriste $u$ analizama financijskih izvještaja i interpretacijama dobivenih rezultata.

\section{ANALIZA FINANCIJSKIH IZVJEŠTAJA}

Sadržajno analiza podrazumijeva ispitivanje problema. Svako ispitivanje ne mora biti i analiza, a da bi to bila, nužno je postojanje: (a) složenosti predmeta ispitivanja, (b) raščlamba složenih predmeta ispitivanja, (c) primjena određenih postupaka odnosno metoda raščlanjivanja, (d) sintetiziranje rezultata radi formiranja zaključaka i (e) mišljenje i interpretacija. Nijedna analiza nije sama sebi svrha već je ona sredstvo za stvaranje određenih prosudbi i pružanje informacija zainteresiranim korisnicima.

Analiza financijskih izvještaja možemo smatrati sredstvom kojim se pribavljaju informacije o financijskom stanju i uspješnosti poslovanja poduzetnika, koja teži stvaranju mišljenja o financijskom stanju i uspješnosti poslovanja proteklog razdoblja, kao i mišljenju o mogućnostima budućeg poslovanja i donošenju poslovnih odluka kojima će se to realizirati. „Međutim, s obzirom na to da je predmet analize bilansa stanja i bilansa uspjeha, smatra 
se da je zajednički cilj svake analize bilanca ocjena financijskog stanja i rentabilnosti (Krasulja, 1973. str. 89.).

Financijsko stanje i uspješnost poslovanja rezultat je niza pojedinačnih odluka o investicijama, poslovanju i financiranju., koje kontinuirano donosi menadžment (uprava) poduzeća. Zato se financijsko stanje u kontekstu donošenja tih odluka može promatrati kao kumulativni rezultat investicijskih i financijskih odluka, a uspješnost poslovanja s pomoću neto učinka poslovanja (dobiti ili gubitka) u određenom razdoblju prema utjecaju na vlasničku glavnicu (Tintor, 2014., str. 42). Stoga se i analiza financijskih izvještaja primarno raspravlja s aspekta upravljanja poslovanjem i razvojem, što podrazumijeva i proces planiranja.

Povezanost analize financijskih izvještaja i poslovnih odluka može se razmatrati kao proces analiziranja i kao proces informiranja. Najprije se analizira djelotvornost poslovanja analiziranjem financijskog stanja, uspješnosti poslovanja, tokova novca i promjena na kapitalu nastalih kao posljedica poslovnih odluka i odluka o financiranju, a potom se dobiveni pokazatelji oblikuju i interpretiraju prema korisnicima informacija, za poboljšanja djelotvornosti poslovanja ili kao informacijska podloga za planiranje, poslovno odlučivanje i upravljanje poduzetnika.

Da bi ispunila očekivanja korisnika informacija, analiza financijskih izvještaja mora sustavno provesti ispitivanje složenog objekta ispitivanja. Dvije su standardne metode kojima to čini: (a) raščlanjivanje, da bi se utvrdio kvalitativan sustav i struktura složenog elementa, a za što je pretpostavka složenost elementa ispitivanja i (b) uspoređivanje kvantitativnih odnosa, da bi se vidjela njegova razvojna tendencija, a za što je uvjet postojanje najmanje dvije veličine koje se uspoređuju. Osim standardnih u ispitivanju se koriste i posebne (specijalne) metode triju skupina: (a) metoda odnosa vrijednosti, kojom se odnos između dvaju skupina podataka iskazuje kao brojčano iskazani omjer, (b) metoda indeksnih brojeva ili metoda trenda, kojom se apsolutni brojevi iz financijskih izvještaja određene godine izjednačuju sa 100 , a potom se stavke sljedećih godina preračunavaju na osnovu prve godine kao bazne, i (c) metoda standardizacije, kojom se dobiveni pokazatelji uspoređuju sa standardnim ili drugim referentnim veličinama, a što predstavlja zadnju kariku u analizama financijskih izvještaja i prosudbi djelotvornosti poslovanja. U procesu analize financijskih izvještaja moguće se koristiti nizom različitih postupaka, (Tintor, 1983., str. 137.), koji su utemeljeni na raščlanjivanju i uspoređivanju.

Klasifikacija postupaka analize financijskih izvještaja, kao temeljna sredstva i postupke koji se rabe $u$ analizi financijskih izvještaja podrazumijeva: (a) komparativne financijske izvještaje, odnosno postupke horizontalne analize koji nam pružaju informaciju o promjenama pozicija financijskih izvještaja tijekom nekoliko obračunskih razdoblja i uočavanje tendencija s pomoću serije indeksa, (b) strukturne financijske izvještaje, odnosno postupke vertikalne analize koji nam pružaju informaciju o promjenama u strukturi financijskih izvještaja i (c) financijski pokazatelji koji nam pojedinačno ili kao skupina, sustav ili zbrojni sintetički pokazatelji pružaju temeljne informacije za poslovno odlučivanje. Za potrebe ove analize koristimo bilancu i račun dobiti i gubitka odabranog poduzeća. 


\section{HORIZONTALNA I VERTIKALNA ANALIZA FINANCIJSKIH IZVJEŠTAJA}

Horizontalna i vertikalna analiza financijskih izvještaja su temeljni instrument i postupak analize financijskih izvještaja. Pomoću horizontalne ili komparativne analize uočavamo tendencije i dinamiku promjena pojedinih pozicija financijskih izvještaja. Inačica horizontalne analize jest i analiza trenda kojem se pomoću postotaka kroz duže razdoblje promatra dinamika promjena pozicija financijskih izvještaja. Vertikalna ili strukturna analiza nam omogućava uvid u strukturu i promjene u strukturi financijskih izvještaja.

\subsection{Horizontalna analiza financijskih izvještaja}

Značajan izvor financijskih informacija lako se može vidjeti ako istovrsne podatke iz financijskih izvještaja za dvije ili više godina prikažemo jedne pored u odgovarajućoj tabličnoj formi. Takav prikaz financijskih izvještaja naziva se komparativnim financijskim izvještajem. Komparativni financijski izvještaji koji služe kao podloga za provedbu horizontalne analize mogu se razmatrati u kontekstu uspoređivanja. Horizontalnom analizom nastoje se uočiti tendencije i dinamika promjena pojedinih pozicija temeljnih financijskih izvještaja. Na temelju tih promjena prosuđuje se kakva je uspješnost i sigurnost poslovanja promatranog poduzeća (Gulin, Tušek i Žager, 2004.,str. 179). Smatra se primarnim oblikom ispitivanja financijskih izvještaja, jer se ispitivanje svodi na utvrđivanje apsolutne i/ ili postotne razlike među istovrsnim podacima za razdoblje dvije ili više godina. Tijekom postupka analize financijskih izvještaja koristili smo podatke odabranog poduzeća koje prema računovodstvenim kriterijima pripada skupini srednje velikih društava. Reduciranjem pozicija bilance i računa dobiti i gubitka, željeli smo poboljšati preglednost podataka i olakšati provođenje postupka analize.

Komparativni prikaz nam pomaže u sagledavanju da li se poslovanje poboljšava ili pogoršava. Međutim, za korištenja i interpretacije podataka potrebni su nam određeni standardi s kojima bi uspoređivali dobivene informacije, odnosno prema kojima bi mogli prosuđivati da li je pokazatelj do kojeg su došli povoljan ili nije. Tri su takva standarda u primjeni: (1) uspješnost poslovanja poduzeća u prošlosti, (2) uspješnost poslovanja konkurentskih poduzeća iste djelatnosti, i (3) prosječni pokazatelji grane djelatnosti poduzeća. Iz prikazanog komparativnog računa dobiti i gubitka vidljivo je da je u odnosu na prošlost došlo do značajnog rasta prihoda i sporijeg rasta rashoda, što je rezultiralo značajnim rastom dobiti. Takav rezultat utjecao je i na pozitivne strukturne promjene u bilanci. Zadržavanjem dobiti u poslovanju, značajno se mijenja struktura aktive u korist kratkotrajne imovine i rasta radnog kapitala i likvidnosti, dok se u pasivi povećava kapital i rezerve i smanjuju kratkoročne obveze. Međutim, tek usporedbom s konkurencijom ili prosjekom grane djelatnosti može se donijeti zaključak o uspješnosti poslovanja. Osim ocjene prošlih kretanja, komparativni prikaz nam pomaže i u procjeni budućih trendova, ali je tu potrebno biti oprezan jer se okruženje i uvjeti u kojima se poslovalo mogu vrlo lako promijeniti.

\subsection{Vertikalna analiza financijskih izvještaja}

Analiza financijskih izvještaja koja omogućava međusobno uspoređivanje pojedinih elemenata strukture financijskih izvještaja radi otkrivanja promjena i važnosti međusobnih 
odnosa pojedinih pozicija financijskih izvještaja. Uobičajena sredstva koja se rabe u vertikalnoj analizi jesu strukturni financijski izvještaji. „Strukturni financijski izvještaji koji služe kao podloga za provedbu vertikalne analize mogu se razmatrati u kontekstu raščlanjivanja. Vertikalna analiza omogućava uvid u strukturu financijskih izvještaja“ (Gulin, Tušek i Žager, 2004.,str. 179).

Strukturiranje se postiže tako da se odredi bazna pozicija financijskog izvještaja koja se izjednačava sa 100 , a potom se sve druge pozicije strukture izračunavaju kao postotak od bazne pozicije. Strukturiranje bilance provedeno je tako da se ukupna aktiva i pasiva izjednačavaju sa 100, a potom se sve pozicije aktive odnosno pasive izračunavaju kao postotak od ukupne aktive ili pasive. Slično je i sa strukturiranjem računa dobiti i gubitka. Ukupni se prihod izjednačava sa 100 , a potom se sve pozicije računa dobiti i gubitka izračunavaju kao postotak od ukupnog prihoda. Prilikom strukturiranja bilance i računa dobiti i gubitka korištene su reducirane pozicije financijskih izvještaja, kako bismo olakšali provođenje postupka analize, te postigli veću preglednost podataka i usporedivost podataka.

Uobičajeno je da se pri provođenju analize financijskih izvještaja komparativni (horizontalni) prikazi bilance odnosno računa dobiti i gubitka, odvojeno prikazuju od strukturiranog (vertikalnog) prikaza bilance i računa dobiti i gubitka. Međutim, radi racionalnijeg prikaza materije u istim smo tablicama dali prikaz komparativnog i strukturnog financijskog izvještaja, s tim da je ovaj potonji prikazan u dva zadnja, osjenčana, stupca prikazanih tablica.

U obje tablice, u prve dvije kolone iskazani su apsolutni iznosi pojedinih pozicija, zatim su u sljedećoj koloni prikazani apsolutni iznosi povećanja pojedinih pozicija, a potom i postotno povećanje. Zadnje dvije osjenčane kolone korištenu su za sažeti prikaz strukturne bilance i računa dobiti i gubitka.

Tablica 1 Sažeta komparativna i strukturna bilanca (u tisućama kuna)

\begin{tabular}{|l|c|c|c|c|c|c|}
\hline AKTIVA & $\mathbf{2 0 \times 1 .}$ & $\mathbf{2 0 \times 2}$ & Iznos +/- & $\mathbf{\% + / -}$ & $\begin{array}{c}\text { Struktura } \\
\mathbf{2 0 \times 1}(\mathbf{\%})\end{array}$ & $\begin{array}{c}\text { Struktura } \\
\mathbf{2 0 x 2}(\%)\end{array}$ \\
\hline A. Dugotrajna imovina & $\mathbf{9 . 0 8 1}$ & $\mathbf{7 . 1 1 5}$ & $\mathbf{( 1 . 9 6 6 )}$ & $\mathbf{( 2 1 , 1 6 )}$ & $\mathbf{2 4 , 3 6}$ & $\mathbf{1 7 , 8 6}$ \\
\hline 1. nematreijalna & 1.945 & 1.261 & $(684)$ & $(35,16)$ & 5,22 & 3,17 \\
\hline 2. materijalna & 7.134 & 5.852 & $(1.282)$ & $(17,97)$ & 19,14 & 14,69 \\
\hline 3. financijska & 2 & 2 & 0 & 0 & 0 & 0 \\
\hline 4. potraživanja & 0 & 0 & 0 & 0 & 0 & 0 \\
\hline B. Kratkotrajna imovina & $\mathbf{2 8 . 1 9 2}$ & $\mathbf{3 2 . 7 2 7}$ & $\mathbf{4 . 5 3 5}$ & $\mathbf{1 6 , 0 9}$ & $\mathbf{7 5 , 6 4}$ & $\mathbf{8 2 , 1 4}$ \\
\hline 1. zalihe & 21.092 & 24.969 & 3.877 & 18,38 & 56,59 & 62,67 \\
\hline 2. potraživanja & 6.004 & 6.699 & 695 & 11,58 & 16,11 & 16,81 \\
\hline 3. financijska & 914 & 254 & $(660)$ & $(72,21)$ & 2.45 & 0,63 \\
\hline 4. novac & 1.096 & 789 & 307 & 28,01 & 2,94 & 1,98 \\
\hline 5. AVR & 0 & 17 & 17 & 0 & 0 & 0,04 \\
\hline C. UKUPNA (A+B) & $\mathbf{3 7 . 2 7 3}$ & $\mathbf{3 9 . 8 4 2}$ & $\mathbf{2 . 5 6 9}$ & $\mathbf{6 , 8 9}$ & $\mathbf{1 0 0 , 0 0}$ & $\mathbf{1 0 0 , 0 0}$ \\
\hline
\end{tabular}




\section{Nastavak tablice 1}

\begin{tabular}{|l|c|c|c|c|c|c|}
\hline AKTIVA & $\mathbf{2 0 x 1 .}$ & $\mathbf{2 0 x 2}$ & Iznos +/- & $\mathbf{\% + / -}$ & $\begin{array}{c}\text { Struktura } \\
\mathbf{2 0 \times 1} \text { (\%) }\end{array}$ & $\begin{array}{c}\text { Struktura } \\
\mathbf{2 0 x 2} \text { (\%) }\end{array}$ \\
\hline PASIVA & & & & & & \\
\hline A. Kapital i rezerve & $\mathbf{1 0 . 4 8 1}$ & $\mathbf{1 4 . 6 8 3}$ & $\mathbf{4 . 2 0 2}$ & $\mathbf{4 0 , 0 9}$ & $\mathbf{2 8 , 1 2}$ & $\mathbf{3 6 , 8 5}$ \\
\hline 1. Upisani kapital & 2.820 & 2.820 & 0 & 0 & 75,71 & 7,08 \\
\hline 2. Rezerve & 559 & 559 & 0 & 0 & 1,50 & 1,40 \\
\hline 3. Zadržana dobit & 5.726 & 7.103 & 1.377 & 24,05 & 15,36 & 17,83 \\
\hline 4. Dobit poslovne godine & 1.377 & 4.202 & 2.025 & 147,06 & 3,69 & 10,55 \\
\hline B. Dugoročne obveze & $\mathbf{1 . 5 8 4}$ & $\mathbf{3 . 1 7 4}$ & $\mathbf{1 . 5 9 0}$ & $\mathbf{1 0 0 , 3 8}$ & $\mathbf{4 , 2 5}$ & $\mathbf{7 , 9 7}$ \\
\hline 1. Obveze prema bankama & 1.584 & 3.174 & 1.590 & 100,38 & 4,25 & 7,97 \\
\hline C. Kratkoročne obveze & $\mathbf{2 5 . 2 0 7}$ & $\mathbf{2 1 . 9 8 6}$ & $\mathbf{( 3 . 2 2 1 )}$ & $\mathbf{( 1 2 , 7 8 )}$ & $\mathbf{6 7 , 6 3}$ & $\mathbf{5 5 , 1 8}$ \\
\hline 1. Prema bankama & 4.475 & 2.820 & 1.655 & 36,98 & 12,01 & 7,08 \\
\hline 3. Predujmovi & 211 & 192 & $(19)$ & 9,00 & 0,06 & 0,48 \\
\hline 3. Dobavljači & 16.219 & 12.330 & $(3.889)$ & $(23,98)$ & 43,51 & 30,95 \\
\hline 4. Zaposlenici & 335 & 382 & 47 & 14,02 & 0,90 & 0,96 \\
\hline 5. Porezi i sl. & 1.486 & 2.534 & 1.048 & 70,52 & 3,99 & 6,36 \\
\hline 6. Ostale obveze & 2.421 & 3.626 & 1.205 & 49,77 & 6,50 & 9,10 \\
\hline 7. PVR & 60 & 102 & 42 & 70,00 & 0,16 & 0,26 \\
\hline D. UKUPNO (A+B+C) & $\mathbf{3 7 . 2 7 3}$ & $\mathbf{3 9 . 8 4 2}$ & $\mathbf{2 . 5 6 9}$ & $\mathbf{6 , 8 9}$ & $\mathbf{1 0 0 , 0 0}$ & $\mathbf{1 0 0 , 0 0}$ \\
\hline
\end{tabular}

Izvor: rad autora, 2019.g.

Tablica 2 Sažeti komparativni i strukturni račun dobiti i gubitka (u tisućama kuna)

\begin{tabular}{|l|c|c|c|c|c|c|}
\hline OPIS & $\mathbf{2 0 \times 1 .}$ & $\mathbf{2 0 \times 2}$ & Iznos +/- & $\mathbf{\% + / -}$ & $\begin{array}{c}\text { Struktura } \\
\mathbf{2 0 \times 1}(\mathbf{\%})\end{array}$ & $\begin{array}{c}\text { Struktura } \\
\mathbf{2 0 \times 2} \text { (\%) }\end{array}$ \\
\hline A. Poslovni prihodi & $\mathbf{1 0 1 . 2 9 1}$ & $\mathbf{1 2 3 . 9 4 2}$ & $\mathbf{2 2 . 6 5 1}$ & $\mathbf{2 2 , 3 6}$ & $\mathbf{9 9 , 7 0}$ & $\mathbf{9 9 , 8 7}$ \\
\hline B. Poslovni rashodi & $\mathbf{9 9 . 2 4 7}$ & $\mathbf{1 1 8 . 4 9 6}$ & $\mathbf{1 9 . 2 4 9}$ & $\mathbf{1 9 , 3 9}$ & $\mathbf{9 7 , 0 5}$ & $\mathbf{9 5 , 4 8}$ \\
\hline 1. materijalni troškovi & 90.710 & 106.108 & 15.398 & 16,97 & 89,22 & 85,50 \\
\hline 2. troškovi osoblja & 5.106 & 5.780 & 674 & 13,20 & 5,02 & 4,66 \\
\hline 3. amortizacija & 699 & 1.490 & 791 & 113,16 & 0,69 & 1,20 \\
\hline 4. ostali troškovi & 763 & 1.113 & 350 & 45,87 & 0,75 & 0,90 \\
\hline 5. ostali rashodi & 1.968 & 4.004 & 2.036 & 103,46 & 1,92 & 3,23 \\
\hline C. Financijski prihodi & $\mathbf{3 4 2}$ & $\mathbf{1 6 5}$ & $\mathbf{( 1 7 7 )}$ & $\mathbf{( 5 1 , 7 5 )}$ & $\mathbf{0 , 3 0}$ & $\mathbf{0 , 1 3}$ \\
\hline D. Financijski rashodi & $\mathbf{7 0 3}$ & $\mathbf{4 8 1}$ & $\mathbf{2 2 2 2 )}$ & $\mathbf{( 3 1 , 5 7 )}$ & $\mathbf{0 , 6 9}$ & $\mathbf{0 , 3 9}$ \\
\hline E. UKUPNI PRIHODI & 101.633 & 124.107 & 22.474 & 22,11 & 100,00 & 100,00 \\
\hline F. UKUPNI RASHODI & 99.951 & 118.977 & 19.026 & 19,04 & 98,35 & 95,87 \\
\hline G. Dobit prije poreza & $\mathbf{1 . 6 8 2}$ & $\mathbf{5 . 1 2 9}$ & $\mathbf{3 . 4 4 7}$ & $\mathbf{2 0 , 4 9}$ & $\mathbf{1 , 6 5}$ & $\mathbf{4 , 1 3}$ \\
\hline H. Porez na dobit & 305 & 928 & 623 & 20,43 & 0,30 & $\mathbf{0 , 7 5}$ \\
\hline I. Neto dobit razdoblja & $\mathbf{1 . 3 7 6}$ & $\mathbf{4 . 2 0 1}$ & $\mathbf{2 . 8 2 5}$ & $\mathbf{2 0 5 , 3 1}$ & $\mathbf{1 , 3 5}$ & $\mathbf{3 , 3 8}$ \\
\hline
\end{tabular}

Izvor: rad autora, 2019.g. 
Iz komparativne analize uočava se značajan rast poslovnih prihoda i sporiji rast poslovni rashoda, što je rezultiralo visokim rastom dobiti u tekućem razdoblju. Financijski prihodi i rashodi imaju nepovoljan odnos te tendenciju pada, a zbog veličine iznosa nemaju značajniji utjecaj na ukupan rezultat poslovanja. Strukturna analiza pokazuje da su poslovni prihodi gotovo izjednačeni s ukupnim prihodima, a da je sporiji rast rashoda rezultirao smanjenjem njihova udjela u strukturi raspodjele ukupnog prihoda, a u korist rasta udjela dobiti. Značajne su promjene u strukturi bilance. Povećana zadržana dobit povećava kapital i njegov udio u strukturi bilance. Istovremeno, pod utjecajem politike financiranja smanjuje se udio kratkoročnih obveza uz manji porast dugoročnih obveza, što ukazuje na jačanje financijske poluge.

\subsection{Analiza trenda}

Za potpunije sagledavanje stanja i poslovanja poduzetnika komparativnom (horizontalnom) analizom potrebno je obuhvatiti financijske izvještaje za što više obračunskih razdoblja. Bolja je mogućnost analize prošlosti i procjene budućih trendova, jer je vjerojatnost sagledavanja promjena uvjeta poslovanja veća ako je analizom obuhvaćeno više obračunskih razdoblja. Prema općeprihvaćenim standardima, minimalnim razdobljem promatranja za uočavanje tendencije kretanja je 5 godina poslovanja. Takva se analiza uobičajeno naziva analiza trenda ili pak trend u postotcima. Naime, da bi se uočila tendencija, umjesto apsolutnih brojeva koriste se relativni, pri čemu se kao bazni indeks koristi realno stanje iz bilance ili računa dobiti i gubitka početne godine promatranja. Trend u postotcima se izračunava za svaku godinu dijeljen originalnog iznosa promatrane pozicije s originalnim iznosom bazne godine.

Tablica 3 Trend u postotcima u računu dobiti i gubitka (u tisućama kuna)

\begin{tabular}{|c|c|c|c|c|c|}
\hline OPIS & $\mathbf{P}-\mathbf{2}$ & $\mathbf{P}-\mathbf{1}$ & $\mathbf{P}$ & $\mathbf{2 0 \times 1}$ & $\mathbf{2 0 \times 2}$ \\
\hline 1. Ukupan prihod & 60.086 & 61.339 & 78.749 & 101.633 & 124.107 \\
\hline$\%$ & $\mathbf{1 0 0}$ & $\mathbf{1 0 2}$ & $\mathbf{1 3 1}$ & $\mathbf{1 6 9}$ & $\mathbf{2 0 7}$ \\
\hline 2. Ukupan rashod & 60.004 & 61.171 & 78.121 & 100.256 & 119.905 \\
\hline$\%$ & $\mathbf{1 0 0}$ & $\mathbf{1 0 2}$ & $\mathbf{1 3 0}$ & $\mathbf{1 6 7}$ & $\mathbf{2 0 0}$ \\
\hline 2. Neto dobit & 82 & 168 & 628 & 1.377 & 4.202 \\
\hline$\%$ & $\mathbf{1 0 0}$ & $\mathbf{2 0 5}$ & $\mathbf{7 6 6}$ & $\mathbf{1 6 7 9}$ & $\mathbf{5 1 2 4}$ \\
\hline
\end{tabular}

Izvor: rad autora, 2019.g.

Za očekivati je da rast prihoda rezultira i rastom bruto i neto dobiti. U ovom je slučaju vidljiv kontinuirani rast prihoda i znatno brži rast neto dobiti, zbog vrlo malog iznosa neto dobiti koji služi kao baza. Tijekom perioda recesije u kojem je poduzetnik radio gotovo bez dobiti, poslovanje je restrukturirano novim kadrovima, novim asortimanom i novim kanalima prodaje, što je rezultiralo visokim rastom prihoda i visokom stopom rasta neto dobiti, što dovodi do pogrešnog dojma. Naime, dobit još uvijek unatoč visokom rastu u tekućoj godini iznosi oko $4 \%$, što je ispod prosjeka djelatnosti. 
Tablica 4 Trend u postotcima u bilanci (u tisućama kuna)

\begin{tabular}{|l|c|c|c|c|c|}
\hline OPIS & $\mathbf{P}-\mathbf{2}$ & $\mathbf{P}-\mathbf{1}$ & $\mathbf{P}$ & $\mathbf{2 0 \times 1}$ & $\mathbf{2 0 \times 2}$ \\
\hline A. Dugotrajna imovina & 7.588 & 7.578 & 8.032 & 9.080 & 7.115 \\
\hline$\%$ & 100 & 100 & 106 & 120 & $\mathbf{9 4}$ \\
\hline B. Kratkotrajna imovina & 15.924 & 17.906 & 22.911 & 28.192 & 32.710 \\
\hline$\%$ & 100 & 112 & 144 & 177 & $\mathbf{2 0 6}$ \\
\hline C. Kapital & 8.309 & 8.477 & 9.105 & 10.481 & 14.683 \\
\hline$\%$ & 100 & 102 & 110 & 127 & 177 \\
\hline D. Dugoročne obveze & 1.767 & 3.094 & 4.391 & 1.584 & 3.174 \\
\hline$\%$ & 100 & 175 & $\mathbf{2 4 8}$ & $\mathbf{8 9}$ & $\mathbf{1 7 9}$ \\
\hline E. Kratkoročne obveze & 13.329 & 13.670 & 17.442 & 25.147 & 21.884 \\
\hline$\%$ & 100 & 103 & 131 & 189 & 165 \\
\hline
\end{tabular}

Izvor: rad autora, 2019.g.

Analiza trenda u postotcima u bilanci upućuje na pozitivan smjer kretanja, jer sve pozicije $s$ većim ili manjim odstupanjima imaju trend rasta. Dugotrajne imovine nakon investicijskog ciklusa postupno se smanjuje amortizacijom. Međutim, posebno su značajne dvije tendencija. Prva je rast kapitala kao posljedica zadržavanja dobiti, a druga još značajnija jest rast kratkotrajne imovine brži od kratkoročnih obveza, rezultat čega je koeficijent tekuće likvidnosti povećan sa 1,19 na 1,49. Podatak dobiva na značaju doda li se tome da se relativni udio zaliha smanjuje tijekom razdoblja.

\section{POJEDINAČNI I SKUPNI POKAZATELJI FINANCIJSKE ANALIZE}

Najznačajniji pojedinačni i skupni pokazatelji financijske analize su: pokazatelji likvidnosti, pokazatelji zaduženosti, pokazatelji aktivnosti, pokazatelji ekonomičnosti, pokazatelji profitabilnosti i pokazatelji investiranja.

\subsection{Analiza likvidnosti}

Jedan od primarnih podataka za menadžere jest pokazatelj likvidnosti. Nelikvidnost na duže razdoblje vodi ka insolventnosti, pa i do propasti ako se na vrijeme ne poduzmu mjere za poboljšanje likvidnosti. Najčešći pokazatelji likvidnosti jesu koeficijent tekuće likvidnosti (KTL), koeficijent ubrzane likvidnosti (KUL) i koeficijent financijske stabilnosti (KFS). Podloga za izračun pokazatelja su podaci iz bilance i računa dobiti i gubitka poduzeća prikazanih u prednjim tablicama. Pri obradi podataka za pozicije bilance koristimo sljedeće simbole. 
Tablica 5 Pokazatelji likvidnosti

\begin{tabular}{|l|c|c|c|c|}
\hline Pokazatelji & Pozicije & $\mathbf{2 0 x \mathbf { 1 }}$ & $\mathbf{2 0 x 2}$ & Indeks \\
\hline Koeficijent tekuće likvidnosti & Novac / KO & 1,12 & 1,49 & 133 \\
\hline Koeficijent ubrzane likvidnosti & Nova+potraživanje / KO & 0,28 & 0,34 & 121 \\
\hline Koeficijent financijske stabilnosti & DI / K+DO & 0,75 & 0,40 & 53 \\
\hline
\end{tabular}

Izvor: rad autora, 2019.g.

Za razumijevanje dobivenih pokazatelja potrebno je poznavati referentne veličine. Uobičajeno je da koeficijent ubrzane likvidnosti ne bi smio biti manji od 1, koeficijent tekuće likvidnosti ne bi smio biti manji od 2, dok koeficijent financijske stabilnosti mora biti manji od 1. Dobiveni pokazatelju upućuju na pozitivan trend kretanja, s tim da u uvjetima povećanja financijske stabilnosti i rasta pokazatelja likvidnosti, poduzetnik još uvijek nema zadovoljavajući stupanj likvidnosti.

\subsection{Analiza zaduženosti}

Zaduženost podrazumijeva da se poslovanje vodi posuđenim novcem. Najčešći pokazatelji zaduženosti su koeficijent zaduženosti (KZ), koeficijent vlastitog financiranja (KVF) i koeficijent financiranja (KF) i pokriće troškova kamata (PTK). Temeljno je pravilo ako je stopa profitabilnosti veća od kamatne stope poduzetnik će imati koristi od zaduživanja. Međutim, svako smanjenje stope profitabilnosti sugerira poduzetniku da bi, ako ima dovoljno novca, trebalo vratiti pozajmice po visokim kamatnim stopama. Stupanj zaduženosti interesira i bankare, jer manja zaduženost daje veći stupanj zaštite od kreditora.

Tablica 6 Pokazatelji zaduženosti

\begin{tabular}{|l|c|c|c|c|}
\hline Pokazatelji & Pozicije & $\mathbf{2 0 x 1}$ & $\mathbf{2 0 x 2}$ & Indeks \\
\hline Koeficijent zaduženosti & UO / UI & 0,72 & 0,63 & 88 \\
\hline Koeficijent vlastitog financiranja & K/ UI & 0,28 & 0,37 & 132 \\
\hline Koeficijent financiranja & UO / K & 2,55 & 1,71 & 67 \\
\hline Pokriće troškova kamata & $\begin{array}{c}\text { Dobit prije poreza i } \\
\text { kamate/ kamate }\end{array}$ & 3,39 & 11,64 & 343 \\
\hline
\end{tabular}

Izvor: rad autora, 2019.g.

Udio kapitala (glavnice) u ukupnoj imovini i odnos glavnice i ukupnih obveza govori u kojoj se mjeri imovina financira od dioničara (udjeličara) a u kojoj od kreditora. Nema univerzalnog kriterija za navedene odnose. Međutim, nizak udio glavnice s gledišta dioničara donijet će visoku korist što je profitna stopa veća od kamatne stope koja se plaća kreditorima. Prema dobivenim podacima uočava se da poduzetnik smanjuje zaduženost i povećava udio vlastitog financiranja, što je moguće zaključiti i na temelju povećanja koeficijenta pokrića troškova kamata. 


\subsection{Analiza aktivnosti}

Analiza aktivnosti provodi se na temelju podataka iz bilance i računa dobiti i gubitka. Mjere se pomoću koeficijenata obrta. Najčešće su to: koeficijent obrta ukupne imovine (KOU), koeficijent obrta kratkotrajne imovine (KOKI), koeficijent obrta potraživanja (KOP) i koeficijent naplate potraživanja u danima (VN). Analiza aktivnosti interesantna je kratkoročnim kreditorima, bankama ili dobavljačima potencijalnim partnerima, jer daje odgovore na sposobnost poduzetnika da generira dovoljno obrtnih sredstava (radnog kapitala) za tekuće poslovanje i redovito plaćanje tekućih obveza. Radni kapital predstavlja višak tekuće imovine iznad tekućih obveza poduzetnika. Kvaliteta radnog kapitala mjeri se (a) strukturom kratkotrajne imovine i (b) vremenom naplate potraživanja odnosno koliko je potrebno da se nenovčani oblici tekuće imovine pretvore u novac.

Tablica 7 Pokazatelji aktivnosti

\begin{tabular}{|l|c|c|c|c|}
\hline Pokazatelji & Pozicije & $\mathbf{2 0 x \mathbf { 1 }}$ & $\mathbf{2 0 \times 2}$ & Indeks \\
\hline Koeficijent obrta UI & UP / UI & 2,73 & 3,12 & 114 \\
\hline Koeficijent obrta KI & UP / KI & 3,61 & 3,79 & 105 \\
\hline Koeficijent obrta potraživanja & $\begin{array}{c}\text { Prihod od prodaje / } \\
\text { Potraživanja }\end{array}$ & 16,87 & 18,50 & 110 \\
\hline Koeficijent naplate potraživanja & Broj dana u godini / KOP & 22 & 20 & 90 \\
\hline
\end{tabular}

Izvor: rad autora, 2019.g.

Prema dobivenim pokazateljima uočava se povoljna aktivnost poduzetnika s trendom rasta, na što upućuje povećanje svih koeficijenata, posebice koeficijenta obrta potraživanja kojim se skraćuje vrijeme naplate potraživanja mjereno brojem dana u godini. Usporedba sa stanjem u grupaciji, kao i s opće obveznim vremenom naplate to potvrđuje. Procjena je da na to među inom znatno utječe gotovinska i kartična maloprodaja.

\subsection{Analiza ekonomičnosti}

Analiza ekonomičnosti usmjerena je ka cilju mjerenja u kojoj mjeri i koliko svaka jedinica rashoda generira ostvareni veći prihod. Pokazatelji ekonomičnosti izračunavaju se na temelju podataka iz računa dobiti i gubitka. Prema tome oni upućuju na odnos prihoda i rashoda, odnosno pokazuju koliko se prihoda ostvari na svaku jedinicu rashoda. Najčešći pokazatelji ekonomičnosti jesu: ekonomičnost ukupnog poslovanja (EUP), ekonomičnost poslovanja (EO) i ekonomičnost financiranja (EF). Koeficijenti ekonomičnosti uvijek bi trebali biti veći od 1 jer samo takav odnos pokazuje da su na svaku jedinicu rashoda ostvareni veći prihodi. 
Tablica 8 Pokazatelji ekonomičnosti

\begin{tabular}{|l|c|c|c|c|}
\hline Pokazatelji & Pozicije & $\mathbf{2 0 \times 1}$ & $\mathbf{2 0 \times 2}$ & Indeks \\
\hline $\begin{array}{l}\text { Ekonomičnost ukupnog } \\
\text { poslovanja }\end{array}$ & $\begin{array}{c}\text { Ukupni prihodi/ Ukupni } \\
\text { rashodi }\end{array}$ & 1,01 & 1,15 & 114 \\
\hline Ekonomičnost poslovanja & $\begin{array}{c}\text { Poslovni prihodi / } \\
\text { Poslovni rashodi }\end{array}$ & 1,04 & 1,08 & 104 \\
\hline Ekonomičnost financiranja & $\begin{array}{c}\text { Financijski prihod/ } \\
\text { Financijski rashod }\end{array}$ & 0,49 & 0,34 & 69 \\
\hline
\end{tabular}

Izvor. rad autora, 2019.g.

Dobivene pokazatelji upućuju na tendenciju rasta i relativno zadovoljavajući odnos, jer ekonomičnosti ukupnog poslovanja jer na svaku jedinicu ostvaruje 1,15 jedinica prihoda, kao i ekonomičnosti poslovanja s povećanjem sa 1,04 na 1,08 jedinica prihoda ili $15 \%$ i $8 \%$ bruto zarade. Stanje ekonomičnosti financiranja ne zadovoljava jer je koeficijent manji od 1 , ali to ne utječe bitno na ukupnu ekonomičnost jer je udio financijskih prihoda i rashoda malen.

\subsection{Analiza profitabilnosti}

Profitabilnost pokazuje efikasnost poslovanja poduzetnika. Najvažniji pokazatelji jesu: marža profita (MP), rentabilnost imovine (R) i rentabilnost kapitala (RK). Izračunavaju se na temelju podataka iz bilance i računa dobiti i gubitka. Marža profita pokazuje efikasnost poslovanja prije nego se plati cijena (kamata) na angažirane pozajmice. Za razliku od rentabilnosti imovine koja pokazuje efikasnost korištenja ukupnog kapitala, rentabilnost kapitala pokazuje efikasnost korištenja vlastitog kapitala. Osim za menadžere i vlasnike, ove su informacije interesantne i za kreditore u kojem ih slučaju interesira EBIT koji pokazuje odnos dobiti prije poreza uvećano za kamate i ukupnog prihoda.

Tablica 9 Pokazatelji profitabilnosti

\begin{tabular}{|l|c|c|c|c|}
\hline Pokazatelji & Pozicije & $\mathbf{2 0 x \mathbf { 1 }}$ & $\mathbf{2 0 \times 2}$ & Indeks \\
\hline Marža profita (MP) \% & Neto dobit i kamate/ UP & 2,05 & 3,77 & 184 \\
\hline EBIT & $\begin{array}{c}\text { Dobit prije poreza i } \\
\text { kamate/ UP }\end{array}$ & 2,35 & 4,52 & 192 \\
\hline Rentabilnost imovine (R) \% & Neto dobit i kamate / UI & 5,58 & 11,76 & 211 \\
\hline Rentabilnost kapitala (RK) \% & Neto dobit / Kapital & 12,88 & 28,62 & 222 \\
\hline
\end{tabular}

Izvor: rad autora, 2019.g.

Marža profita je u prethodnom razdoblju ispod prosjeka grupacije s tim da je povoljan trend njezina rasta. Za razliku od toga, pokazatelji rentabilnosti imovine i rentabilnosti kapitala zadovoljavajući su u obje promatrane godine, a imaju i povoljan trend kretanja jer u tekućoj godini imaju rast prema prethodnoj godini. 


\subsection{Analiza investiranja}

Najvažniji pokazatelji koji interesiraju investitori jesu pokazatelji investiranja. To je skupina pokazatelja koja govori koliko je novčanih jedinica dobiti ostvareno po dionici (udjelu), odnosno kolika je dividenda po dionici, te kakav je odnos cijene i dobiti po dionici. Najvažniji pokazatelji investiranja jesu: dobit po dionici (EPS), dividenda po dionici (DPS) odnos cijene i dobiti po dionici $(P / E)$, rentabilnost dionice ukupno (RDU), rentabilnost dionice dividendna (RDD), kao i tržna cijena po dionici (PPS)

Predmetom analize su financijski izvještaji srednje velikog društva, koje nije dioničko već je riječ o društvu s ograničenom odgovornosti a broj udjela prema knjizi udjela jest pet jednakih udjela, pa ćemo u ovom dijelu analize pojam dionice koristiti kao sinonim za udjele. Također, dionice (udjeli) društva ne kotiraju na tržištu (burzi) pa smo kao tržišnu cijenu preuzeli prosječnu cijenu jednog udjela u iznosu 564.000,00 kn. Politika društva je zadržavanje i ulaganje dobiti i posljednjih godina pa u promatranom razdoblju nema isplate dividende, dijelom i zbog visokih poreznih nameta na isplatu dividende. Međutim u tekućoj i prethodnoj godini rezerviran je iznos 500.000,00 kuna i 750.000,00 na ime isplate dobiti.

Tablica 10 Prikaz obračuna isplaćene dobiti (u tisućama kuna)

\begin{tabular}{|l|c|c|c|c|c|}
\hline OPIS & $\mathbf{P - 2}$ & $\mathbf{P}-\mathbf{1}$ & $\mathbf{P}$ & $\mathbf{2 0 \times 1}$ & $\mathbf{2 0 \times 2}$ \\
\hline 1. Zadržana dobit & 4.848 & 4.930 & 5.098 & 5.726 & 7.103 \\
\hline 2. Dobit tekuće godine & 82 & 168 & 628 & 1.377 & 4.201 \\
\hline 3. Ukupno & 4.930 & 5.098 & 5.726 & 7.103 & 7.304 \\
\hline 4. Isplaćeno & 0 & 0 & 0 & 0 & 0 \\
\hline
\end{tabular}

Izvor: rad autora, 2019.g.

Tablica 11 Pokazatelji investiranja (u tisućama kuna)

\begin{tabular}{|l|c|c|c|c|}
\hline Pokazatelji & Pozicije & $\mathbf{2 0 x \mathbf { 1 }}$ & $\mathbf{2 0 x \mathbf { 2 }}$ & Indeks \\
\hline 1. EPS & Neto dobit / broj dionica & 126 & 275 & 212 \\
\hline 2. DPS & Dio dobiti za isplatu / broj dionica & 100 & 150 & 150 \\
\hline 3. P/E & Tržna cijena dionice / EPS & 4,48 & 2,05 & 46 \\
\hline 4. RDU, \% & Dobit po dionici /PPS & 22 & 49 & 222 \\
\hline 5. RDD, \% & Dividenda po dionici / PPS & 18 & 27 & 150 \\
\hline
\end{tabular}

Izvor: rad autora, 2019.g.

Korištenje ovog hipotetičkog predloška isplate dividende ne bi korisnika informacije trebalo dovoditi u zabludu, kao niti visina tekuće i zadržane dobiti. Naime, dobit se ne isplaćuje preko pet godina, pa iako relativno visoka ukupno zadržana dobit u odnosu prema ukupno ostvarenom prihodu $u$ istom razdoblju od posljednjih pet godina, čini svega oko $1,67 \%$ ukupno ostvarenih prihoda u tom razdoblju. 


\section{SUSTAVI POKAZATELJA I SINTETIČKI POKAZATELJI}

Prethodno prikazani pojedinačni pokazatelji odnose se na pojedine segmente poslovanja. Stoga je bez obzira na njihov broj, ograničeno njihovo korištenje radi zaključivanja o cjelini. Na određeni način to se odnosi i na pojedine skupne pokazatelje. Zbog toga se za sagledavanje cjeline koriste različiti složeni pokazatelji. „Pod sustavom ili sistemom pokazatelja podrazumijeva se izbor odgovarajućih pokazatelja, odgovarajući način njihova povezivanja ili odgovarajuća zavisnost i sveukupna zavisnost pojedinih pokazatelja i njihovog povezivanja s ciljem“(Tintor, 1983., str. 124). Najčešće se koristimo sa dva složena sustava pokazatelja, Du Pontovim sustavom analitičkih pokazatelja i Altmanovim Z-score sintetičkim pokazateljem financijske sigurnosti.

\subsection{Du Pontov sustav pokazatelja}

Du Pontov sustav pokazatelja nastao je kao potreba sagledavanja cjeline problema i koristi se ponajprije za potrebe planiranja poslovanja, poslovnog odlučivanja i razvoja poduzetnika. On odražava najviši cilj rada i poslovanja poduzetnika. Za poduzetnike se kao najvažniji pokazatelj stanja, poslovanja i opravdanosti ulaganja ističe rentabilnost ukupne imovine. Izračun se temelji na umnošku marže profita (neto dobit+kamate/ poslovni prihodi) i koeficijenta obrta ukupne imovine (poslovni prihodi/ ukupna imovina). Shematski se sustav najčešće prikazuje u piramidnom obliku, tako da je na vrhu piramide prikazana rentabilnost ukupne imovine. Korištenjem podataka iz financijskih izvještaja za promatrana obračunska razdoblja, dobiveni postotak rentabilnosti imovine za 20x1 godinu iznosi $5,46 \%$, a za $20 \times 2$. godinu iznosi $12,48 \%$. Riječ je o visokoj stopi rentabilnosti korištenja imovine. Pored toga trend njezina kretanja je pozitivan. Takvi podaci ohrabruju poduzetnika na ulaganja jer su ostvarene stope rentabilnosti iznad kamatnih stopa na pozajmice.

\subsection{Altmanov Z-score sintetički pokazatelj}

Jedan je od najznačajnijih sintetičkih (zbrojnih) pokazatelja koji se mogu izračunati na temelju podataka iz financijskih izvještaja. Čini ga skup niza ponderiranih podataka. Nastao je kao plod istraživanja ekonomskih analitičara radi procjene mogućnosti propasti poduzetnika u budućem razdoblju, a na temelju podataka iz financijskih izvještaja. Izračunava se po formuli: $Z=1,2 \times X 1+1,4 \times X 2+3,3 \times X 3+0,6 \times X 4+1,0 \times X 5$. Da bismo ga izračunali, potrebno je izračunati vrijednosti elemenata $\mathrm{X} 1-\mathrm{X} 5$.

Tablica 12 Izračun elemenata strukture Z pokazatelja

\begin{tabular}{|l|l|l|c|c|}
\hline Koeficijent & Brojnik & Nazivnik & $\mathbf{2 0 \times 1}$ & $\mathbf{2 0 \times 2}$ \\
\hline X1 & tekuća imovina-tekuće obveze & ukupna imovina & 0,08 & 0,27 \\
\hline X2 & zadržana dobit & ukupna imovina & 0,15 & 0,18 \\
\hline X3 & dobit prije kamata i poreza & ukupna imovina & 0,06 & 0,14 \\
\hline X4 & tržna vrijednost kapitala & ukupne obveze & 0,39 & 0,59 \\
\hline X5 & neto prodaja & ukupna imovina & 2,73 & 3,12 \\
\hline
\end{tabular}

Izvor: rad autora, 2019.g. 
Uvrštavanjem vrijednosti X1-X5 u standardnu formulu izračunat ćemo Altmanov zbrojni pokazatelj mogućnost stečaja poduzetnika, za tekuću i prethodnu godinu.

$$
\begin{aligned}
& Z(20 \times 1)=1,2 \times 0,08+1,4 \times 0,15+3,3 \times 0,06+0,6 \times 0,39+1 \times 2,73=3,51 \\
& Z(20 \times 2)=1,2 \times 0,27+1,4 \times 0,18+3,3 \times 0,14+0,6 \times 0,59+1 \times 3,12=4,50
\end{aligned}
$$

Budući da je referentna veličina ovog pokazatelja koeficijent 3,00, možemo prema ostvarenim koeficijentima zaključiti da poduzetniku u skorom razdoblju ne prijeti opasnost propadanja. Međutim, treba uzimati u obzir da se zaključak temelji na statističkim podacima te da je procjena stanja i kretanja na tržištu važan čimbenik koji utječe na poslovanje u budućnosti.

\section{ZAKLJUČAK}

Financijski izvještaji poduzetnika pružaju informacije o financijskom stanju, uspješnosti poslovanja i promjenama u financijskom položaju poduzetnika, što je menadžerima i drugim zainteresiranima korisno za donošenje njihovih ekonomskih odluka. Međutim, financijski izvještaji ne pružaju sve informacije koje su zainteresiranim korisnicima važne pri donošenju njihovih odluka. U tom je kontekstu, za potrebe upravljanja poslovanjem i razvojem, kao i za potrebe ulagača i investitora, važno je značenje analize financijskih izvještaja koja pruža dodatne informacije potrebne za upravljanje, financiranje ili investiranje poduzetnika.

Analiza financijskih izvještaja važan je izvor informacija poduzetniku i menadžerima za investicijske, financijske i tekuće poslovne odluke. Jednako tako ona pruža dovoljno podataka i svim drugim zainteresiranim partnerima, potencijalnim ulagačima, bankama, državnim institucijama i sl. Dakle, bit analize financijskih izvještaja jest utvrditi djelotvornost i bonitet poslovanja. U postupku analize primjenjuju se različite osnovne i složene metode raščlambe, sintetiziranja i uspoređivanja, a što smo pojasnili u tekstu rada.

Primjenom navedenih postupaka i alata u analizi financijskih izvještaja odabranog poduzeća došli smo do značajnih podataka i informacija za ocjenu njegova stanja i poslovanja, kao i procjenu mogućeg budućeg razvoja. Općenito se stječe zaključak da poduzetnik uspješno posluje. Postoji višegodišnji trend rasta opsega poslovanja, prihoda i dobiti. Struktura financiranja prema izvorima i namjeni je pozitivna te je značajan radni kapital i povoljna financijska poluga. lako su pokazatelji likvidnosti nešto ispod standardnih veličina, a pokazatelji profitabilnosti upućuju na relativno nisku maržu profita, složeni i sintetički pokazatelji ukazuju na visoku i povoljnu konačnu ocjenu stanja i rezultata poslovanja poduzetnika, kao i trend njihova rasta.

Promatramo li analizom dobivene podatke i informacije iz financijskih izvještaja odabranog poduzetnika u kontekstu donošenja poslovnih odluka, visoke vrijednosti rentabilnosti imovine kao i njihova tendencija rasta, poticajno su okruženje za donošenje kvalitetnih investicijskih odluka. Također, stanje i trend rasta poslovne aktivnosti, ekonomičnosti i profitabilnosti ukazuju na kvalitetu poslovanja i dobru tržišnu orijentaciju u poslovanja poduzeća, ali i na potrebu djelotvornijeg praćenja i kontrole troškova poslovanja u funkciji kvalitetnijih poslovnih odluka, posebno onih što se odnose na ostale režijske troškove i rashode. Konačno, za odluke o financiranju najznačajniji pokazatelj je rentabilnost vla- 
stitog kapitala koji pokazuje visoke vrijednosti s tendencijom rasta. To je i odgovor zašto poduzetnik smanjuje tuđe izvore financiranja u korist zadržavanja ostvarene dobiti i njezina reinvestiranja, rezultat čega je i promjena strukture izvora financiranja u korist vlastitih trajnih izvora financiranja, povećanje radnog kapitala i sigurnosti poslovanja. 


\title{
ANALYSIS OF THE FINANCIAL STATEMENTS IN THE FUNCTION OF MAKING QUALITY BUSINESS DECISIONS
}

\author{
Željko Tintor, MSc \\ Retra d.o.o. for Audit and Business Consulting in Zagreb \\ Lastovska 6, Zagreb, Croatia \\ E-mail: retra@zg.htnet.hr
}

\section{ABSTRACT}

Adequate information background for interested users is required for business planning and running. Informing users means presenting them with relevant and reliable information in a recognizable form and content, understandable to the intended users. Most of this information comes from accounting. The final product of the accounting process is a set of statements called financial statements. They report on the state of the company and business performance and warn of potential problems. The financial statements drawn up by the entities defined in the Accounting Act are balance sheet, income statement, cash flow statement, statement of changes in equity and notes to the financial statements. Financial reporting must provide: reliable information for management decision-making, usable information for current and potential investors and lenders to make investment and loan decisions, information about entrepreneur's resources and their sources, transactions that affect changes in resources and sources, business performance information over a period of time, as well as information to experts who want to study the state and business of the past in connection with planning, etc. In addition to owners and management, the information about the status and operations of the company may be of interest to other groups, such as business partners, investors, banks, government institutions, etc. With respect to the reasons and motives for observation, each of these groups is focused on certain aspects of financial information. For those with accounting knowledge, a set of financial statements is understandable, and if audited by independent auditors, it is also a reliable source of information for their needs. However, many people are not accounting professionals, and they require proper interpretation of the financial statements. Interpretation involves the analysis of financial statements using a complex financial analysis instrument. Analytical techniques that are used as means of analysis are value and percentage changes, the trend in percentages, components in percentages, and indicators and indicator systems. The paper analyses the financial statements of the selected company using relevant analytical methods and techniques. The aim of this paper is to show how, using analytical methods and techniques, the information presented in the financial statements can be interpreted for the needs of owners and management, creditors and other users.

Keywords: financial statements; financial information; analysis of financial statements; analytical methods and techniques; interpretation of financial statements 


\section{LITERATURA}

1. Gulin, D., Tušek, B., Žager, L. (2004). Poslovno planiranje, kontrola i analiza. Zagreb: HZRFD.

2. Helfert E. A. (1997). Tehnika financijske analize. Zagreb: HZRFD.

3. Krasulja, D. (1973). Finansijska analiza poduzeća. Beograd: Ekonomski fakultet.

4. Meigs\&Meigs (1999). Računovodstvo temelj poslovnog odlučivanja. Zagreb: Mate.

5. Robert N. A., James. S. R. (2004). Računovodstvo, financijsko i upravljačko. Zagreb: RRIF plus.

6. Rodić, J. (1990). Teorija i analiza bilansa. Beograd: Ekonomika.

7. Tintor, Ž. (2014). Analiza financijskih izvještaja. Zagreb: Školska knjiga.

8. Tintor,J. (1983). Uvod u ekonomsku analizu poslovanja OUR-a. Zagreb: Narodne novine.

9. Vasiljević, K. (1970). Teorija i analiza bilansa. Beograd: Savremena administracija.

10. Žager, K., Mamić Sačer, I., Sever, S., Žager, L. (2008). Analiza financijskih izvještaja. Zagreb: Masmedia. 